chief ways in which a bird can fly without flapping : (a) gliding spirally upwards in an ascending current; (b) using the rapid increase of wind with height near the surface of the ocean during strong winds; (c) steering so as to use the turbulence within strong winds. The principles involved were laid down by Rayleigh half a century ago. But observers of birds in the tropics have not usually been trained physicists, and have known little of Rayleigh's work or of measurements made in wind-tunnels; so when they have tried to interpret what they saw, their handling has at times confused the issues. Accordingly, the serial contains extracted statements that one would be sorry to defend : that birds cannot soar in ascending currents when there is no wind (pp. 2,3), or that a bird can travel over a plain for miles dead on to a gale without change of height or using ascending currents (pp. 3, 5). Soaring without a wind has often been seen; and sailing for long periods in a gale has been dominated by turbulence so that it has been very changeable in direction. As the last date on an extract is 1923 , we hope that the next issue will contain the results of the successful expedition of Idrac to Africa to examine the soaring conditions. Doubtless also use will be made of the experience of the soaring that is now an essential feature of the gliding movement. The interest in soaring and sailing flight is rapidly growing, and tends to air-mindedness ; so all success to this new venture.

\section{Jaguars at the London Zoo}

For more than a year, the Gardens of the Zoological Society of London could show no specimen of the jaguar. It is welcome news, therefore, that two fine adults have just been purchased by the Society. The jaguar, the largest of the New World Felidæ, seems now to be by no means common in its native wilds, which range from Texas to Patagonia. To the general public, this animal is of interest on account of its handsome coloration, which appeals even more intensively to the naturalist, who will once more be enabled to make comparisons with the leopard and other spotted cats. For this particular pattern is among them presented in many forms more or less closely correlated with their mode of life. In both leopard and jaguar this pattern takes the form of more or less complete rings of black on a tawny background. With the jaguar a central spot of black is generally present in the centre of the ring. Thus a series of 'rosettes' is formed running in longitudinal lines, forming a 'concealing coloration' in very diverse surroundings ; for both leopard and jaguar are great tro-climbers. This is specially true of the jaguar, which makes its way among the great branches in a series of prodigious bounds in pursuit of monkeys. On the ground, owing to its large size, it is enabled to prey upon animals as large as the tapir, and in times of scarcity on cattle and horses. It displays a marked preference for the neighbourhood of water, where it battens on that giant rodent the capybara, varying its menu with turtles and their eggs, alligators, and fish. Unfortunately, this animal rarely breods in captivity; but transferred to Whipsnade, they might be induced to do so.

\section{Culture Contacts in Buckinghamshire}

Arguments for the diffusion of culture are so frequently a matter of inference, resting on a balance of probabilities, that any instance of the effect of extraneous cultural influence, which rests on wellattested historical evidence, is a welcome accession to the material of discussion. An instructive lesson may be derived from a letter from Mrs. Wishaw, the well-known authority on Spanish archæology and cultural history, appearing in The Times of January 24, in which she directs attention to the relation between the pillow-laces of Buckinghamshire and those still made on occasion at Niebla in the Province of Huelva, which derives in the English county from the interest taken in it by Katherine of Aragon, the consort of Henry VIII. Not only does Mrs. Wishaw record a tradition still current in Huelva connecting the Spanish princess with the Andalusian lace; but she also points out that at the present day this lace retains in its motifs the prehistoric Egyptian fivepetalled lotus and the birds of life on either side brought to Andalusia by Coptic workers, who introduced the art into Spain in the eighth century A.D. under the rule of the Yemenite Arabs. Thus we have a tenuous if well-attested line of connexion between 'prehistoric' Egypt and Britain, which might well have been called in, in default of documentary evidence, to support the famous prehistoric blue faience Egyptian bead (now assuredly crushed under the weight that has been laid upon it!), and to 'prove' the existence of a culture complex in Britain. The moral would seem to be that an attitude of caution is necessary towards the bold hypotheses of cultural movements, which carry no intrinsic evidence of the chronological relation of their component elements. An analogous instance is the resemblance between the arts of early China, Polynesia and Central America, to which attention has been directed, where the time gaps may aggregate as much as two thousand years or more.

\section{Roman Cemetery at Verulamium}

THE exploration of Verulamium by Dr. R. E. Mortimer Wheeler has added importance and interest to any finds in what may be termed subsidiary areas in the vicinity. Local archæologists, fortunately, are fully alive to the importance of this branch of investigation in their studies; and the St. Albans and Hertfordshire Archæological Society has undertaken a comprehensive survey of an area in the parish of St. Stephen, immediately to the south of the site of Roman Verulamium. Here in the churchyard a glass burial urn was found in 1848, and other finds have been made since then at various times, though without any precise records being kept. The work of the survey has been carried out by Dr. Norman Davey, assisted by a band of voluntary helpers. The erection of some cottages on the south side of King Harry Lane, which runs in a north-westerly direction towards the Roman wall from the churchyard, made it possible to collect sufficient evidence to establish the position of forty cremation burials and a brick-lined cremation chamber. A small strip of waste land on the north side of the lane was also thrown open to 
investigation by the owner, and has proved rich in finds. Of these, one of the most interesting, according to a preliminary account which appeared in The Times of January 24, is a structure, which proved to be the abutment of a bridge carrying a track over a ditch. On the east side of the track were two cremation burials and on the west side forty-two cremation burials and two inhumations, one of a child and one of an adult. No sort of order or alignment seems to have been observed. None of the pottery is certainly later than A.D. 160, but it is interesting as showing the development in design from Belgic to Roman. Of the forty-four cremation burials twenty-one consisted of the urn only; but the remaining twenty-three included smaller vessels, beakers, jugs, dishes of Samian ware, and a small glass tear bottle. A report by Dr. Davey will be presented to the Society shortly.

\section{Empire Exhibition at Johannesburg}

THE rapid development of South Africa was outlined by Lord Riverdale of Sheffield, speaking on January 23, under the auspices of the British Empire League, at the British Empire Club. His main subject was the Empire Exhibition which is to be opened in Johannesburg on September 15. Last year marked the twenty-fifth anniversary of the Union of South Africa; between 1910 and 1935 the European population increased by more than fifty per cent and the native population by more than forty per cent. These important years have seen a tremendous increase in agricultural products and mineral development. Conspicuous progress has been made in the fruit industry, the value of exports of fresh fruit having risen from an average of $£ 15,000$ a year in pre-War years to $£ 2,270,000$ in 1934 . In recent years rapid industrial development has also taken place. As an export market for United Kingdom goods, South Africa ranks second only to British India, and in 1934 took goods to the value of some

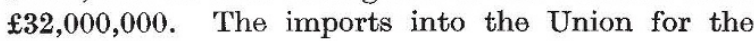
first six months of 1935 showed an increase of $£ 5,600,000$, and of this total the United Kingdom supplied forty-nine per cent. This will be the first Empire Exhibition which has been held outside Great Britain and is receiving the full support of the Union of South Africa Government and the Government of Great Britain. After enumerating many of the features of the forthcoming exhibition, Lord Riverdale said that, from a business point of view, he could thoroughly recommend it as being an opportunity of showing what British manufacturers can do for the South African market with a view to the expansion of our trade. In metals and manufactures, including machinery and vehicles, South Africa imported more than $£ 24,000,000$ in 1934, and Great Britain supplied only $£ 12,000,000$ in this item alone. If the market was studied and our goods shown in the right way, there lies a large field for further expansion. The same might be said for the item of fibres, yarns, textiles and apparel. In 1934 the Union's total imports for these were $15 \frac{1}{2}$ millions, of which the United Kingdom's share was less than $£ 10,000,000$.

\section{The National Institute of Sciences of India}

WE welcomed recently (NATuRE, 135, 59, 410 (1935) ) the formation in India of the National Institute of Sciences, a major function of which will be the co-ordination of the activities of the three co-operating academies in Calcutta, Allahabad and Bangalore. We have now received the first two volumes of the Proceedings of the now Institute. The first volume contains a full account of the inaugural meeting together with a list of the foundation fellows. We have referred already to the scholarly address by the president, Sir Lewis Leigh Fermor, and a perusal of the list of foundation fellows shows that the Institute has received the enthusiastic support of all men of science working in India. In the past, India has suffered in that it has had no body of organised scientific opinion capable of representing it at international conferences. It is not the least notable of the functions performed by the Indian Science Congress that it has been responsible for the foundation of the Indian Institute of Sciences, which will supply this want.

THE second volume of the Proceedings prints a number of scientific communications read before the Institute. They cover a wide field of research since they comprise papers on botanical, anthropological, physical and chemical subjects. We had not anticipated from the president's inaugural address that the Institute would, in other than exceptional circumstances, act as a publishing body; but that it was to be concerned rather with the publication of summaries of papers read before the co-operating academies. We regard it as somewhat unfortunate that there should be an increase in the large number of journals already published in India. Of greater interest than the specialist papers is the account of the symposium on "Problems of the Ionosphere". The holding of these general discussions on varied subjects of scientific importance will, we think, prove to be one of the most notable activities of the National Institute, and if they maintain the high standard of the first symposium, original work in India will receive a marked stimulus.

\section{Recent Acquisitions at the Natural History Museum}

Amovg recent additions to the zoological collections are specimens of Ungulate mammals from the Sudan presented by Major P. H. G. Powell-Cotton and Miss Diana Powell-Cotton. A fine specimen of adult beaver from Norway has been purchased, and an interesting series of Crustacea from the Bering Sea and the Sea of Okhotsk, regions previously very poorly represented in the Museum collection, have been received by exchange. A specimen of a rare mollusc, Halicardia flexuosa, from the Atlantic Ocean off Cape Point, South Africa, has been presented by the director of the South African Museum, Cape Town. The Department of Geology has recently acquired, through the generosity of the Committee of the Torquay Natural History Society, more than 160 Devonian invertebrates from Devon, all of which are type or figured specimens ; and has received from 